International Journal of Physical Sciences and Engineering
Available online at http://sciencescholar.us/journal/index.php/ijpse
Vol. 2 No. 3, December 2018, pages: $1 \sim 9$
e-ISSN : 2550-6943, p-ISSN : 2550-6951
https://doi.org/10.29332/ijpse.v2n3.190

\title{
Challenges and Technical Requirements for Integration of Renewable Energy Sources in Cuban Electric System
}

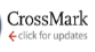 \\ Miguel Castro Fernandez a, Miriam Vilaragut Lanes b, Miriam Lourdes Filgueiras Sains de Rozas c, Ariel \\ Santos Fuentefria d, Maria Rodriguez Gamez ${ }^{\mathrm{e}}$ \\ Article history: Received 10 April 2018, Accepted: 25 August 2018, Published: 11 September 2018

\section{Correspondence Author a}

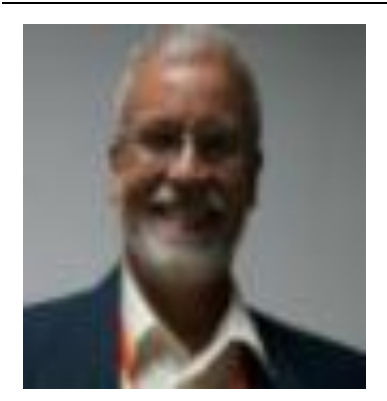 \\ Keywords \\ Distributed generation; \\ Microgrids; \\ Renewable energy \\ sources; \\ Sustainable development;

\begin{abstract}
The decision of the Cuban Government to massively introduce Renewable Energy Sources (RES) as a way to change the energy matrix, and in particular, the electricity matrix, is presented as an opportunity to introduce not only sources of energy friendly with the environment, but also make the contributions that, without limiting the development of the country, respond to the UN Millennium Development Goals (UNMDG). However, the large-scale use of RESs in an electrical system such as Cuba, isolated and not interconnected to other systems, can have a group of challenges that must be taken into consideration when it is exploited, since it does not incorporate only new technologies, some of which depend on weather conditions such as solar, wind and hydro technology for the production of electricity, but allow us to think about the introduction of emerging technologies that can increase the penetration of RES in the electrical system and introduce new management concepts, both territorially and nationally. The present work reflects on this, from some experiences that have been analyzed in different research works carried out at CIPEL, plus other international experiences.
\end{abstract}

Weather conditions;

e-ISSN: 2550-6943, p-ISSN: 2550-6951 ๑Copyright 2018. The Author. SS Journals Published by Universidad Técnica de Manabí. This is an open-access article under the CC BY-SA 4.0 license (https://creativecommons.org/licenses/by-sa/4.0/) All rights reserved.

\footnotetext{
a Ph.D. Centro de Investigaciones y Pruebas Electroenergéticas (CIPEL), Facultad de Ingeniería Eléctrica, Universidad Tecnológica de La Habana José Antonio Echeverría, Cujae, La Habana, Cuba

b Ph.D. Centro de Investigaciones y Pruebas Electroenergéticas (CIPEL), Facultad de Ingeniería Eléctrica, Universidad Tecnológica de La Habana José Antonio Echeverría, Cujae, La Habana, Cuba

c Ph.D. Centro de Investigaciones y Pruebas Electroenergéticas (CIPEL), Facultad de Ingeniería Eléctrica, Universidad Tecnológica de La Habana José Antonio Echeverría, Cujae, La Habana, Cuba)

d Ph.D. Centro de Investigaciones y Pruebas Electroenergéticas (CIPEL), Facultad de Ingeniería Eléctrica, Universidad Tecnológica de La Habana José Antonio Echeverría, Cujae, La Habana, Cuba

e Ph.D. Univesidad Tecnica de Manabi, Portviejo, Ecuador
} 


\section{Contents}

Abstract

1. Introduction...

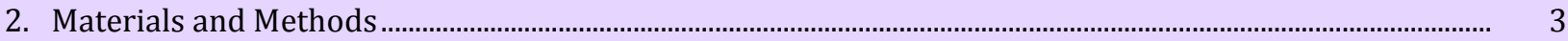

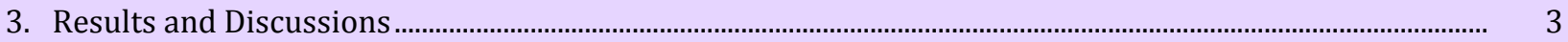

Challenges to overcome with the introduction of RES in Cuba ................................................................................ 3

Limit of integration of RES in Cuba ...............................................................................................................................

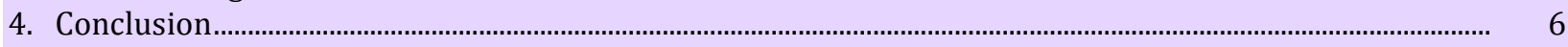

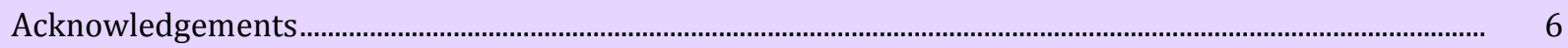

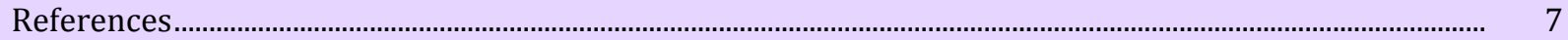

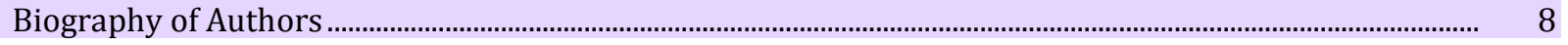

\section{Introduction}

At the beginning of the electrical industry, the demand of any locality was satisfied by the installations of generators distributed in it. Subsequently, with the increasing increase in the demand for electricity, large generating plants were started to be built, generally close to the primary sources of energy (example: coal, hydroelectric plants), which gave rise to the current large power electric systems (de Juana Sardón: 2003, Shien et al.: 2009).

At present, the growth of the electricity market, accelerated technical progress and the development of capital markets was determining factors in the emergence of the development of different generation technologies, which are based on generating using relatively small plant sizes with respect to the conventional generation. This new type of generation, known as Distributed Generation, Dispersed Generation or Generation in Situ, has allowed to solve some problems that the expansion of the electrical systems present at present, such as the losses in the lines before the need to transmit the energy to great distances, increases in the volumes of investments when having to raise the levels of tension of work and to become more expensive the infrastructures of transmission, diminution of the quality of the energy that arrives at the user, etc. (Shayani \& de Oliveira (2011).).

Cuba, within the framework of the Energy Revolution, developed a Program for the Introduction of Distributed Generation as a way to increase the reliability of the National Electric Power System (SEN), which allowed the additional installation of hundreds of generation nodes and changing the typology thereof, which places Cuba in an enviable position to go hand in hand with current trends in the international energy sector, which has been characterized in recent years by:

1. The transition towards greater diversification of generation sources (with an important role of renewable energy sources (RES)), which is creating opportunities and establishing new challenges for the security associated with the global energy infrastructure.

2. The development of smart technologies, which is creating new opportunities, but also threats.

3. The balance between energy generation and demand, which is leading to a new order of global energy security.

The Sustainable Development Goals (SDGs), also known as the Global Objectives, are a universal call for action to end poverty, protect the planet and ensure that all people enjoy peace and prosperity (ANSI-IEEE, 2017). For Cuba, the fulfillment of the strategic objectives contained in the country's energy policy is related to the introduction of the RESs in its electrical system (Galván, 2017), which brings with it several challenges that must be overcome, among which the following stand out: potentials and FRE technologies with greater prospects for the country, make a truly complete technology transfer of it and define the management scheme of the SEN-based on the characteristics of the selected RES technologies, in order to ensure the highest efficiency of its use, including the auxiliary services it requires (Ramos et.al.: 2018, Cedeño et al.: 2017, Gámez et al.: 2017). 


\section{Materials and Methods}

During the investigation, the inductive method was applied, based on observation as the primary basic method that allowed distinguishing and recording the essential technical elements that take place during the FRE penetration in the electrical system (SE), being able to classify their impacts and arrive at precise conclusions on the subject studied. We reviewed 58 bibliographies published on the web, including essays and scientific articles published in academic journals of different levels, books, reports, standards, manuals, and other technical publications, of which 10 were chosen to refer them to the work. In order to carry out the penetration analysis of the photovoltaic technology network, it was necessary to take into account the current conditions of the Cuban SEN, where the following technical requirements are considered:

a) Very low penetration level: when the presence of the FRE is considered negligible for the SE; there is no technical reason to demand that they remain connected and cover cargo in the event of a contingency in the SE, so they can be disconnected.

b) Low penetration level (between 3\% and 5\%): In this case, FRE facilities can collaborate in the solution of some contingencies, so they can be requested to stay connected and deliver reactive power in case of voltage dips, as well as active power in case the frequency exceeds the upper threshold in the so-called dead band.

c) Average penetration level (between 6\% and 20\%): FRE facilities can be required to collaborate in the quality of ordinary service such as the regulation of reactive power depending on the voltage at a point and limit the variation ramps of power.

d) High penetration level (more than 20\%): FRE facilities may be required to maintain the stability of the system, attending to the service or, in the event of a disconnection, having some type of generation reserve associated, such as accumulation systems or reserves. in hot with fossil fuels, so that it is able to support the operation of the system.

\section{Results and Discussions}

\section{Challenges to overcome with the introduction of RES in Cuba}

In the direction of defining the FRE potentials and technologies with greater prospects for the country and allowing the sustainability of the FRE program in Cuba, it should not be forgotten that the FREs have been integrated into the power electric systems based on the technological development itself. Have had their own systems and in the evolution that the electric networks have presented over the years shown in figure 1

Fernandez, M. C., Lanes, M. V., Rozas, M. L. F. S. de, Fuentefria, A. S., \& Gamez, M. R. (2018). Challenges and technical requirements for integration of renewable energy sources in Cuban electric system. International Journal of Physical Sciences and Engineering, 2(3), 1-9. https://doi.org/10.29332/ijpse.v2n3.190 


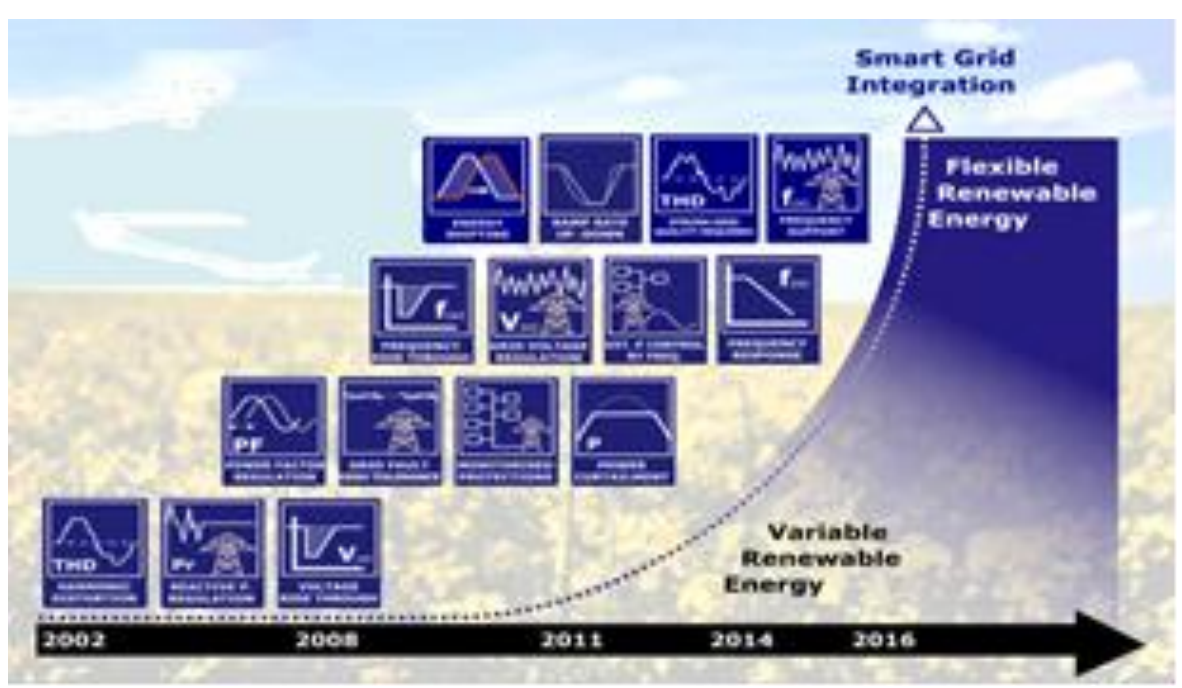

Figure 1. Evolution of the FREs in function of the development of the electrical networks (Govea \& González, 2016)

All this has demanded improvements to the RES technologies and the evolution in the not too distant future towards an intelligent electrical network. In this regard, we should not forget either, in a summary of the historical context, that with the introduction of the concept of DG in the Power Electric Systems (SEP), different situations of their integration have been raised, which have been settled through of technical recommendations that have resulted in national standards, in some cases, and international standards in others; an example of them can be seen in the recommendations offered by the series of standards ANSI-IEEE 1547 (Almaral \& Gonçalves, 2011), that addresses the issue of the interconnection of distributed sources with the SEPs and whose successive updates have been responding to these challenges, including the partial and / or massive introduction of the RES. Taking into consideration the above, and the current conditions of the Cuban SEN, it is possible to demand a group of technical requirements from the RESs, which are shown in table 1

Table 1

Technical requirements can be required of RESs according to the penetration level in the electrical system

\begin{tabular}{|c|c|}
\hline $\begin{array}{l}\text { Level of } \\
\text { penetration }\end{array}$ & Technical requirements \\
\hline $\begin{array}{l}\text { Very low (less } \\
\text { than } 3 \% \text { ) }\end{array}$ & $\begin{array}{l}\text { The presence of the RES can be considered negligible for the electrical system (SE); } \\
\text { they should not be required to remain connected, and to cover cargo, in the event of } \\
\text { a contingency in the SE, so they can be disconnected from them. }\end{array}$ \\
\hline $\begin{array}{l}\text { Low } \\
\text { (3 to } 5 \%)\end{array}$ & $\begin{array}{l}\text { RES installations can collaborate in the solution of some contingencies, so they can } \\
\text { be requested to stay connected and deliver reactive power in case of voltage dips, } \\
\text { as well as active power in case the frequency exceeds the upper threshold in the call } \\
\text { dead band. }\end{array}$ \\
\hline $\begin{array}{l}\text { Medium } \\
\text { (5 to } 20 \% \text { ) }\end{array}$ & $\begin{array}{l}\text { It may be required that the RES facilities collaborate in the quality of the ordinary } \\
\text { service such as the regulation of reactive power depending on the voltage at a point } \\
\text { and limit the power variation ramps. }\end{array}$ \\
\hline $\begin{array}{l}\text { High } \\
\text { (More than 20\%) }\end{array}$ & $\begin{array}{l}\text { It can be required that the RES installations maintain the stability of the system, } \\
\text { attending the service or in case of disconnection having associated some type of } \\
\text { generation reserves such as accumulation systems or hot reserves with fossil fuels } \\
\text { so that it is capable of supporting the operation of the system. }\end{array}$ \\
\hline
\end{tabular}

With the aim of ensuring a real transfer of technology from the RESs, it is necessary to ensure a process of absorbing knowledge of each of the RES technologies that happens not only by being able to demand and obtain from the suppliers all the information related to the draft; but also of a process of continuous training that seeks, 
on the one hand, the strengthening of the base link of the system that make up the operators and specialists who work directly with the technologies, while on the other, it allows the continuous training and assimilation of the possibilities of these technologies on the part of the engineers who are dedicated to the control, analysis, maintenance and management of the same at the different levels, as shown in figure 2.

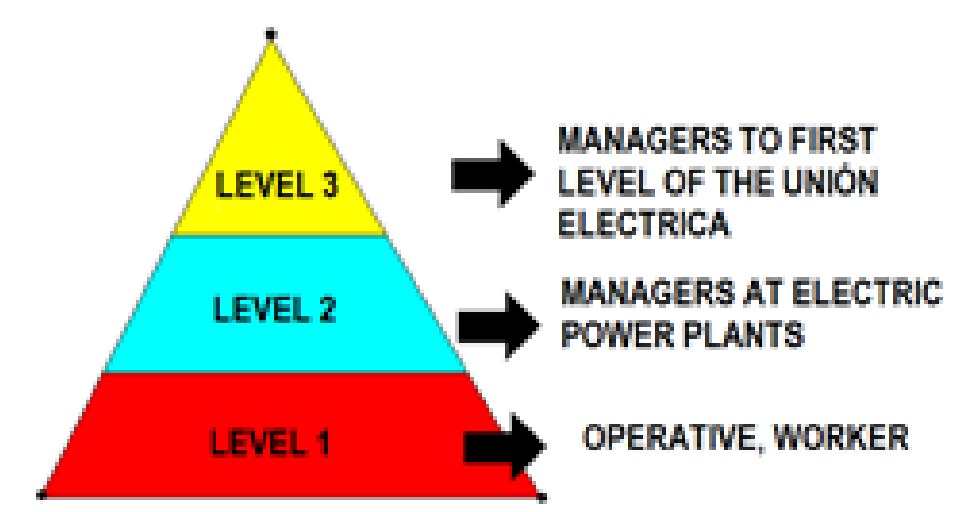

Figure 2. Outline of training levels associated with the concept of absorption of technological capacity

With regard to the management of the system, under the new conditions imposed by the RES, the main objective is to limit its influence on the effects of voltage variation on the connection nodes, and even on the frequency of the system itself.

There are many ways to address this problem, including the use of FACTS (flexible AC transmission systems (SVC, STATCOM or similar)) technologies, but one of them is the determination of the power limits of RES that can be connected to each node of the system, either in the $110 \mathrm{kV}$ network or in the distribution network of 13 and $34.5 \mathrm{kV}$. This is a study that must be done yet, there is time to do it and it would justify, really, how far we can include the FRE in the SEN without the need for additional technologies. For example, studies that have been conducted in the area and connection point where the wind farms of Herradura 1 and Herradura 2 are located show that it is possible to connect up to $200 \mathrm{MW}$ at said point of connection to the network, without the need for additional technologies, without problems of voltage stability at that point, which does not justify the presence of FACTS systems in these wind farms that are actually $100 \mathrm{MW}$ altogether (Santos et.al.: 2012).

The technical requirements and operating and operating procedures for the RES generating units that are connected to the SEN are expressed in the current Network Code; however, there are two aspects that are not part of the network code but influence the results that are obtained or will be obtained:

a) The real efficiency of the RES schemes currently connected to the network.

b) The assimilation of the current RES technologies by operators and specialists in the design, operation, and exploitation of the same.

For example, a $1 \%$ of low efficiency that has in the technology of the photovoltaic parks (PFV) is equivalent to $17 \mathrm{GWh}$ stopped generating when the proposed plan for 2018 is fulfilled of having about $289 \mathrm{MW}$ of generation FV integrated to the network. Then, some questions arise before these results:

1) What are the elements or technical issues that are affecting the efficiency of these systems?

2) Are technical problems or organizational problems that are affecting these results?

3) Is it a problem of the technologies that are being installed or is it a problem that we are not correctly exploiting them?

Fernandez, M. C., Lanes, M. V., Rozas, M. L. F. S. de, Fuentefria, A. S., \& Gamez, M. R. (2018). Challenges and technical requirements for integration of renewable energy sources in Cuban electric system. International Journal of Physical Sciences and Engineering, 2(3), 1-9. https://doi.org/10.29332/ijpse.v2n3.190 
Limit of integration of RES in Cuba

Taking into account all of the above, it is then necessary to define the possible limits of integration of the RESs in the Cuban SEN.

1) How can much energy from the FRE be integrated into the SEN? The answer is feasible to obtain, under two considerations:

a) Without using any additional compensation or supplementary scheme (storage, FACTS, etc.).

b) Using some additional compensation or complementary technology

To answer this question it is necessary to define the Power Limits (LP) that are feasible to connect in each node under the worst working conditions, and from there, obtain the maximum power that would be feasible to connect to the SEN. The rationale for this criterion is in studies conducted inside and outside the country (Galván. et.al.: 2017), (Govea et al, 2016), (Santos et.al.: 2012), as well as in the consideration that the Cuban SEN is not, like other systems, feasible to connect to other networks; it is an isolated system, without connection to others that can help in the face of given contingencies, such as in North, Central, and South America, or in Europe itself. For this reason, Cuba has only its generating sources and the capacity of its technicians and operators to maintain the stability of the system, so that the massive presence of the RES in it puts at stake the exploitation of all technical and human resources. that they own.

That is why the way to analyze and define how much RES can be connected to the Cuban SEN cannot be approached in the same way as it has been done for many years, since:

a) The system has changed and will change more, with a high prevalence of the Distributed Generation in the generation schemes

b) The possible presence, in the not too distant future, of generation even on the side of the client, incorporating the concept of management by the client, means that the way of controlling and operating the system tends to a greater automation of the system, and even to have an "intelligent" system, which will obviously change the paradigms of control and operation of the Cuban SEN.

c) The integration of technologies not present today, such as electric vehicles to support frequency control, will also change the management of the Cuban SEN.

\section{Conclusion}

It shows the need that the country has to introduce new management schemes in the SEN from the penetration of the FRE, starting from the knowledge that it is a system with very specific characteristics since it is not interconnected to any other power electrical system and only with its own renewable energy resources.

\section{Acknowledgments}

The authors would like to thank the editor of IJPSE for their support, valuable time, advice. 


\section{References}

Cedeño, M. L. D., Arteaga, M. G. D., Pérez, A. V., \& Arteaga, M. L. D. (2017). Regulatory Framework for Renewable Energy Sources in Ecuador Case Study Province of Manabí. International Journal of Social Sciences and Humanities (IJSSH), 1(2), 29-42.

de Juana Sardón, J. M. (2003). Energías renovables para el desarrollo. Editorial Paraninfo.

Galván E. et.al. (2017). GPTech CUBA Grid-Interactive Plants. Presentación realizada durante visita al CIPEL, febrero.

Gámez, M. R., Pérez, A. V., Será, A. S., \& Ronquillo, Z. M. (2017). Renewable Energy Sources and Local Development. International Journal of Social Sciences and Humanities (IJSSH), 1(2), 10-19.

Govea R.C.J, González M. C. A. (2016), Cálculo del límite de potencia eólica en los puntos de conexión de los parques eólicos Herradura 1 y Herradura 2, trabajo de diploma en opción al título de Ingeniero Electricista, Facultad de Ingeniería Eléctrica, Cujae, La Habana, Cuba,

IEEE Standards Association. (2003). 1547-2003-IEEE Standard for Interconnecting Distributed Resources with Electric Power Systems. IEEEStd.: Piscataway Township, NJ, USA.

Objetivos de Desarrollo Sostenible ODS), Agenda 2030 de la ONU, accessible en: https://www.undp.org/content/undp/es/home/ sustainable-development-goals.html.

Papathanassiou, S. A., \& Boulaxis, N. G. (2006). Power limitations and energy yield evaluation for wind farms operating in island systems. Renewable energy, 31(4), 457-479. accesible en: https://www.sciencedirect.com/science/article/pii/S0960148105000923

Ramos, J. L. M., Pérez, A. V., Gámez, M. R., \& Zambrano, R. V. H. (2018). Renewable energy sources on the change of energy matrix in Manabí province. International Research Journal of Engineering, IT and Scientific Research, 4(4), 17-29.

Santos F.A. (2017), Metodología para el cálculo del límite de potencia eólica (LPE) en sistemas eléctricos débiles y distribuidos, tesis en opción al grado científico de Doctor en Ciencias Técnicas, Universidad Tecnológica de La Habana José Antonio Echeverría, Cujae, La Habana, Cuba.

Santos, F. A., Frota, J. T., Arruda, B. R., de Melo, T. S., de Castro Brito, G. A., Chaves, M. H., \& Rao, V. S. (2012). Antihyperglycemic and hypolipidemic effects of $\alpha, \beta$-amyrin, a triterpenoid mixture from Protium heptaphyllum in mice. Lipids in health and disease, 11(1), 98.

Shayani, R. A., \& de Oliveira, M. A. G. (2011). Photovoltaic generation penetration limits in radial distribution systems. IEEE Transactions on Power Systems, 26(3), 1625-1631.

Shien, H., Weizhou, W., Huaisen, J., Gang, C., Fujun, W., \& Jun, L. (2009, April). Integration of wind farm into Gansu power grid and its operation. In Sustainable Power Generation and Supply, 2009. SUPERGEN'09. International Conference on (pp. 1-5). IEEE.

Fernandez, M. C., Lanes, M. V., Rozas, M. L. F. S. de, Fuentefria, A. S., \& Gamez, M. R. (2018). Challenges and technical requirements for integration of renewable energy sources in Cuban electric system. International Journal of Physical Sciences and Engineering, 2(3), 1-9. https://doi.org/10.29332/ijpse.v2n3.190 


\section{Biography of Authors}

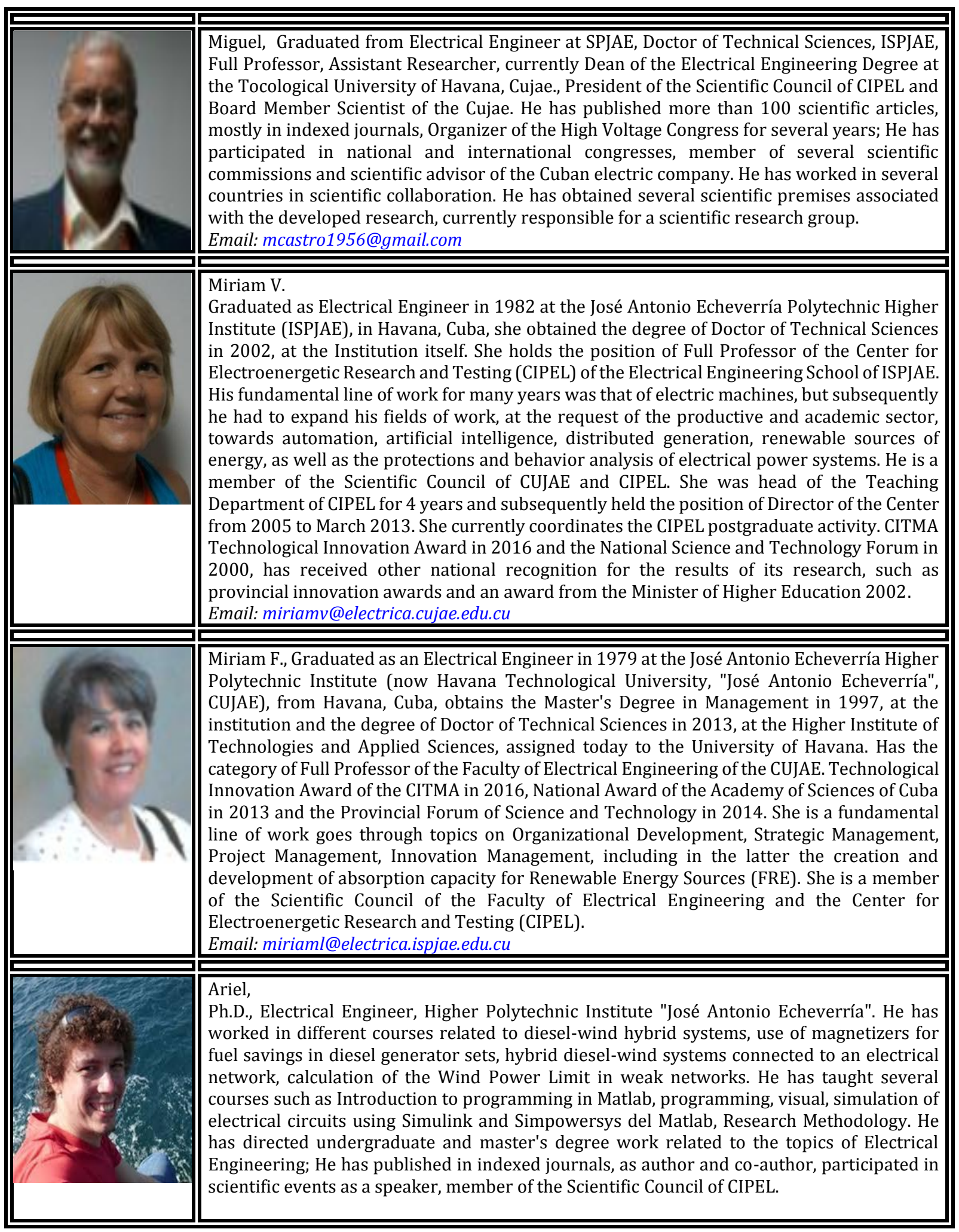




\begin{tabular}{|l|l|}
\hline Lic. in Education, Specialty: Physics and Astronomy, MSc. Planning and Territorial \\
Development (Strategic Planning Renewable sources of energy), Dra. Strategies and Planning \\
of the territory in Renewable Sources of Energy, Pablo de Olavide University, Seville Spain. \\
Professor-Researcher Evaluator of the CYTED and Colciencia program. Evaluator of the \\
Scielo Ecuador magazines. Expert in Energy Renewable Energy programs. Pair evaluator of \\
several national and foreign indexed magazines; author of several books, scientific articles in \\
academic journals, monographs, national and international events; owns 2 patents and 6 \\
copyright protections; member of several international organizations and networks; \\
experience of having participated in more than 53 research projects as a project director and \\
member in different countries such as: Cuba, Mexico, Guatemala, Spain, the Japanese \\
Cooperation Agency (JICA). China and currently in Ecuador. \\
Email: taliangel270557@gmail.com
\end{tabular}

Fernandez, M. C., Lanes, M. V., Rozas, M. L. F. S. de, Fuentefria, A. S., \& Gamez, M. R. (2018). Challenges and technical requirements for integration of renewable energy sources in Cuban electric system. International Journal of Physical Sciences and Engineering, 2(3), 1-9. https://doi.org/10.29332/ijpse.v2n3.190 